\title{
Possible prophylactic or preventive role of topical povidone iodine during accidental ocular exposure to 2019-nCoV
}

\author{
Phulen Sarma $^{1} \cdot$ Hardeep Kaur ${ }^{1} \cdot$ Bikash Medhi $^{1} \cdot$ Anusuya Bhattacharyya ${ }^{2}$ (i) \\ Received: 4 May 2020 / Revised: 8 May 2020 / Accepted: 12 May 2020 / Published online: 20 May 2020 \\ (C) Springer-Verlag GmbH Germany, part of Springer Nature 2020
}

\section{Dear Editor.}

Ocular tropism of respiratory viruses is a well-known fact and is reported in cases of a wide range of viruses, e.g., adenovirus, respiratory syncytial virus, influenza virus, rhino virus, and corona viruses $[1,2]$. Conjunctivitis is present in $3.175 \%$ of patients with COVID-19; however, only $0.703 \%$ of patients present with conjunctivitis as the first presenting feature [2-4] and $1.949 \%$ of patients demonstrate the virus in tear/conjunctival specimen [2]. These findings indicate ocular tropism of SARS-CoV-2. However, there is also a possibility of local replication of the virus followed by systemic involvement, especially in cases of droplet or aerosol transmission through the ocular route [4-7].

The anatomical and molecular link between the ocular system and the respiratory tract is already well-established [2]. The nasolacrimal duct (NLD) serves as an anatomical link between ocular system and respiratory tract [1]. Regarding molecular link, various cellular proteins such as $\alpha 2$-3-linked sialic acid (expressed in lower respiratory tract and ocular tissue) serves as an interaction site for diverse range of influenza viruses [2]. CD46, GD1a glycans act as cellular receptor for adeno virus, desmoglein-2/adenovirus receptor for adenovirus, or the coxsackievirus, ACE2 for SARS-CoV and ACE2 and CD147 for SARS-CoV-2 [1]. In case of SARS-CoV-2,

\author{
Anusuya Bhattacharyya \\ anusuya.8k@gmail.com \\ Phulen Sarma \\ phulen10@gmail.com \\ Hardeep Kaur \\ Aspireachieve.shine@gmail.com \\ Bikash Medhi \\ drbikashus@yahoo.com
}

1 Department of Pharmacology, PGIMER, Chandigarh, India

2 Department of Ophthalmology, Government Medical College and Hospital, Sector 32, Chandigarh, India initial interactions between the spike protein $\mathrm{S} 1$ domain and its host receptor (either ACE2 or CD147) are the initiating event in establishment of human host infection $[8,9]$.

Presence of an ocular renin angiotensin system (RAS) and ACE (angiotensin converting enzyme) activity is already demonstrated in retinal tissue, choroid, and sclera as early as $1988[10,11]$. This was followed by the demonstration of ACE and Ang-II receptor expression in ciliary body (nonpigmented epithelium), cornea (epithelium and endothelium), conjunctiva (epithelium), trabecular meshwork cells, retinal ganglion cells, photoreceptor cells, nuclear layer of retina, and endothelial cell layer of chorioretinal vessels [12]. In vitro studies demonstrate corneal and conjunctival expression of ACE2, thus suggesting a link between the ocular system and respiratory system in case of COVID-19 [13]. Another route of entry of SARS-CoV-2 to human host is through its interactions with CD147 [14], which is present in tear and human ocular tissues, e.g., corneal epithelium, endothelium, keratocytes, conjunctiva, and retinal pigment epithelium [15]. Thus, the conjunctival route may play a major route in establishment of infection [5].

\section{Accidental exposure to SARS-CoV-2 through ocular route}

Though the face is covered with a mask by health care professionals, police, and frontline workers during their interaction with suspected or confirmed COVID-19 patients, the ocular route usually remain uncovered. Though protective goggles are available as a part of personal protection equipment (PPE) kits, however, their scarce availability is a concern even in the developed countries [16]. Thus, ocular route remains unprotected and unattended. Accidental ocular exposure to SARS-CoV-2 can occur in many conditions:

1. Accidental hand-eye contact among persons working in COVID-19 environment. 
2. This issue becomes complicated when news of some incidences like intentional spitting on doctors [17-19] and police personals [20-22] by suspected or confirmed COVID-19 patients, which also can result in accidental ocular exposure.

However, until date, no post-exposure prophylaxis is available in case of accidental ocular exposure with SARS-CoV-2.

\section{Povidone iodine $1 \%$ eye drop as post-exposure prophylaxis: can it have some role?}

Povidone iodine is a broad spectrum antiviral agent covering both enveloped and non-enveloped viruses with established virucidal activity (adenovirus, mumps, rota virus, polio, coxsackie, rhino virus, herpes virus, rubella, measles, influenza, and human immunodeficiency virus) [23]. In rabbit model of adenoviral conjunctivitis, topical povidone iodine along with dexamethasone was found to be very effective [24]. In clinical settings, povidone iodine (5\% and 1\%) already showed clinical benefit in cases of adenoviral conjunctivitis [25-27].

Now, coming to the efficacy of povidone iodine treatment in SARS-CoV, treatment with povidone iodine for $2 \mathrm{~min}$ reduces viral infectivity to below detectable level and the efficiency of povidone iodine was similar to $70 \%$ ethanol in terms of reducing viral infectivity [28]. There are reports citing efficacy of povidone iodine gurgle/mouth wash against SARSCoV and MERS-CoV [29, 30], and on the basis of these findings, povidone iodine mouth wash/gurgle is being recommended in cases of SARS-CoV-2 also [31, 32] by various authors.

In in vitro studies, povidone iodine (1\%) was successful in reducing the infectivity of the virus (both SARS-CoV and MARS-CoV, 1-min time contact period for SARS-CoV and 15-second contact time for MERS-CoV, were associated with significant loss of viral infectivity) [33]. Occurrence of resistance is not an issue with povidone iodine. So, here comes a theoretically potential role of using povidone iodine $1 \%$ locally (eye drop) in case of accidental ocular exposure or in case of 2019-nCoV-associated conjunctivitis. However, toxicity profile of povidone iodine is to be to be considered and we need more clinical data for further validation.

Acknowledgments The authors acknowledge the contribution of Dr. Pramod Avti, Associate Prof, Department of Biophysics, PGIMER, Chandigarh; Manisha Prajapat, PhD scholar, Department of Pharmacology, PGIMER, Chandigarh; Dr. Mukundam Borah, Registrar, Department of Pharmacology, Guwahati Medical College and Hospital Guwahati Assam, India; Nishant Shekhar, Department of Pharmacology, PGIMER, Chandigarh; Dr. Subodh Kumar, NPDF, Department of Pharmacology, PGIMER, Chandigarh; Dr. Dipankar
Das, HOD, Uvea, Neuro Ophthalmology and Ocular Pathology; Sri Sankaradeva Nethralaya, Guwahati, Assam; and Dr. Ajay Prakash, Asst. Professor, Department of Pharmacology, PGIMER, Chandigarh, towards the preparation of the manuscript.

Author contributions Concept: Phulen Sarma and Anusuya Bhattacharyya

Literature research and data extraction: Phulen Sarma, Hardeep Kaur, and Anusuya Bhattacharyya

Manuscript writing, revision of manuscript, and final approval: Phulen Sarma, Hardeep Kaur, Bikash Medhi, Anusuya Bhattacharyya

\section{Compliance with ethical standards}

Conflict of interest The authors declare that they have no conflict of interest.

Abbreviations 2019-nCoV, 2019 novel corona virus; SARS-CoV, Severe acute respiratory syndrome coronavirus; MERS-CoV, Middle East respiratory Syndrome Coronavirus; ACE2, Angiotensin converting enzyme 2; COVID-19, Coronavirus disease 2019; PPE, Personal protective equipment

\section{References}

1. Belser JA, Rota PA, Tumpey TM (2013) Ocular tropism of respiratory viruses. Microbiol Mol Biol Rev 77(1):144-156. https://doi. org/10.1128/MMBR.00058-12

2. Sarma P, Kaur H, Kaur H et al (2020) Ocular manifestations and tear or conjunctival swab PCR positivity for 2019-nCoV in patients with COVID-19: a systematic review and meta-analysis. Soc Sci Res Netw. https://doi.org/10.2139/ssrn.3566161

3. Deng C, Yang Y, Chen H et al (2020) Ocular detection of SARSCoV-2 in 114 cases of COVID-19 pneumonia in Wuhan, China: an observational study. Soc Sci Res Netw. https://doi.org/10.2139/ ssrn. 3543587

4. Sun $X$, Zhang $X$, Chen $X$ et al The infection evidence of SARSCOV-2 in ocular surface: a single-center cross-sectional study. medRxiv. Published online February 26, 2020 : 2020.02.26.20027938. https://doi.org/10.1101/2020.02.26. 20027938

5. Seah I, Agrawal R (2020) Can the coronavirus disease 2019 (COVID-19) affect the eyes? A review of coronaviruses and ocular implications in humans and animals. Ocul Immunol Inflamm 0(0): 1-5. https://doi.org/10.1080/09273948.2020.1738501

6. Li J-PO, Lam DSC, Chen Y, Ting DSW (2020) Novel coronavirus disease 2019 (COVID-19): the importance of recognising possible early ocular manifestation and using protective eyewear. $\mathrm{Br} \mathrm{J}$ Ophthalmol 104(3):297-298. https://doi.org/10.1136/ bjophthalmol-2020-315994

7. Zhou Y, Zeng Y, Tong Y, Chen C (2020) Ophthalmologic evidence against the interpersonal transmission of 2019 novel coronavirus through conjunctiva. Ophthalmology. https://doi.org/10.1101/ 2020.02.11.20021956

8. Prajapat M, Sarma P, Shekhar N et al (2020) Drug targets for corona virus: a systematic review. Indian J Pharmacol 52(1):56. https://doi. org/10.4103/ijp.IJP_115_20

9. Sarma P, Prajapat M, Avti P, Kaur H, Kumar S, Medhi B (2020) Therapeutic options for the treatment of 2019-novel coronavirus: an evidence-based approach. Indian J Pharmacol 52(1):1. https://doi. org/10.4103/ijp.IJP 11920 
10. Ferrari-Dileo G, Ryan JW, Rockwood EJ, Davis EB, Anderson DR (1988) Angiotensin-converting enzyme in bovine, feline, and human ocular tissues. Invest Ophthalmol Vis Sci 29(6):876-881

11. Wagner J, Jan Danser AH, Derkx FH et al (1996) Demonstration of renin $\mathrm{mRNA}$, angiotensinogen $\mathrm{mRNA}$, and angiotensin converting enzyme mRNA expression in the human eye: evidence for an intraocular renin-angiotensin system. Br J Ophthalmol 80(2):159163

12. Savaskan E, Löffler KU, Meier F, Müller-Spahn F, Flammer J, Meyer P (2004) Immunohistochemical localization of angiotensin-converting enzyme, angiotensin II and AT1 receptor in human ocular tissues. Ophthalmic Res 36(6):312-320. https:// doi.org/10.1159/000081633

13. Sun Y, Liu L, Pan X, Jing M (2006) Mechanism of the action between the SARS-CoV S240 protein and the ACE2 receptor in eyes. Int J Ophthalmol 6:783-786

14. Wang K, Chen W, Zhou Y-S et al (2020) SARS-CoV-2 invades host cells via a novel route: CD147-spike protein. Microbiology. https:// doi.org/10.1101/2020.03.14.988345

15. Määttä M, Tervahartiala T, Kaarniranta K et al (2006) Immunolocalization of EMMPRIN (Cd147) in the human eye and detection of soluble form of EMMPRIN in ocular fluids. Curr Eye Res 31(11):917-924. https://doi.org/10.1080/ 02713680600932290

16. Shortage of personal protective equipment endangering health workers worldwide. Accessed April 18, 2020. https:/www.who. $\mathrm{int} /$ news-room/detail/03-03-2020-shortage-of-personal-protectiveequipment-endangering-health-workers-worldwide

17. Coronavirus patient booked for spitting on doctor in Tamil Nadu. Deccan Herald. Published April 12, 2020. Accessed April 15, 2020. https://www.deccanherald.com/national/south/coronavirus-patientbooked-for-spitting-on-doctor-in-tamil-nadu-824472.html

18. Case against coronavirus patient for spitting on doctor in Tamil Nadu: Police. NDTV.com. Accessed April 15, 2020. https://www. ndtv.com/india-news/tamil-nadu-coronavirus-news-case-againstcovid-19-patient-for-misbehaving-with-hospital-staff-in-tam2210604

19. Chennai April 12 AN, April 12 2020UPDATED:, Ist 2020 19:45. Tamil Nadu: Trichy coronavirus patient spits at nurse, booked by police. India Today. Accessed April 15, 2020. https://www. indiatoday.in/india/story/tamil-nadu-trichy-coronavirus-patientspits-at-nurse-booked-by-police-1666211-2020-04-12

20. Man "spat at police and said he had coronavirus." BBC News. https://www.bbc.com/news/uk-england-nottinghamshire52076031. Published March 28, 2020. Accessed April 19, 2020

21. 'There's some Corona for you," Colorado DUI suspect says as she spits on officer, police say.' KIRO. Accessed April 19, 2020. https:// www.kiro7.com/news/trending/theres-some-corona-you-coloradodui-suspect-says-she-spits-officer-police-say/ ETLPYHSL6VAVZNT7MPZ4AMJ62U/

22. Man in Norway jailed for corona spit threat to policeman. Published April 3, 2020. Accessed April 19, 2020. https://www.thelocal.no/ 20200403/man-in-norway-jailed-for-spitting-on-policeman-whilesaying-corona
23. Kawana R, Kitamura T, Nakagomi O et al (1997) Inactivation of human viruses by povidone-iodine in comparison with other antiseptics. Dermatology (Basel) 195(Suppl 2):29-35. https://doi.org/ 10.1159/000246027

24. Clement C, Capriotti JA, Kumar M et al (2011) Clinical and antiviral efficacy of an ophthalmic formulation of dexamethasone povidone-iodine in a rabbit model of adenoviral keratoconjunctivitis. Invest Ophthalmol Vis Sci 52(1):339-344. https://doi.org/10. 1167/iovs.10-5944

25. Pinto RDP, Lira RPC, Abe RY et al (2015) Dexamethasone/ povidone eye drops versus artificial tears for treatment of presumed viral conjunctivitis: a randomized clinical trial. Curr Eye Res 40(9): 870-877. https://doi.org/10.3109/02713683.2014.964419

26. Kovalyuk N, Kaiserman I, Mimouni M et al (2017) Treatment of adenoviral keratoconjunctivitis with a combination of povidoneiodine $1.0 \%$ and dexamethasone $0.1 \%$ drops: a clinical prospective controlled randomized study. Acta Ophthalmol 95(8):e686-e692. https://doi.org/10.1111/aos.13416

27. Pepose JS, Narvekar A, Liu W, Haque R (2019) A randomized controlled trial of povidone-iodine/dexamethasone ophthalmic suspension for acute viral conjunctivitis. Clin Ophthalmol 13:535544. https://doi.org/10.2147/OPTH.S191275

28. Kariwa H, Fujii N, Takashima I (2006) Inactivation of SARS Coronavirus by means of povidone-iodine, physical conditions and chemical reagents. Dermatology (Basel, Switzerland) 212(Suppl 1):119-123. https://doi.org/10.1159/000089211

29. Eggers M, Koburger-Janssen T, Eickmann M, Zorn J (2018) In vitro bactericidal and virucidal efficacy of povidone-iodine gargle/mouthwash against respiratory and oral tract pathogens. Infect Dis Ther 7(2):249-259. https://doi.org/10.1007/s40121018-0200-7

30. Eggers M, Eickmann M, Zorn J (2015) Rapid and effective virucidal activity of povidone-iodine products against Middle East Respiratory Syndrome Coronavirus (MERS-CoV) and Modified Vaccinia Virus Ankara (MVA). Infect Dis Ther 4(4):491-501. https://doi.org/10.1007/s40121-015-0091-9

31. Kirk-Bayley J, Combes J, Sunkaraneni S, Challacombe S (2020) The use of Povidone iodine nasal spray and mouthwash during the current COVID-19 pandemic may reduce cross infection and protect healthcare workers. Soc Sci Res Netw. https://doi.org/10.2139/ ssrn.3563092

32. Mady LJ, Kubik MW, Baddour K, Snyderman CH, Rowan NR (2020) Consideration of povidone-iodine as a public health intervention for COVID-19: utilization as "personal protective equipment" for frontline providers exposed in high-risk head and neck and skull base oncology care. Oral Oncol Published online April 16. https://doi.org/10.1016/j.oraloncology.2020.104724

33. Kampf G, Todt D, Pfaender S, Steinmann E (2020) Persistence of coronaviruses on inanimate surfaces and their inactivation with biocidal agents. J Hosp Infect 104(3):246-251. https://doi.org/10. 1016/j.jhin.2020.01.022

Publisher's note Springer Nature remains neutral with regard to jurisdictional claims in published maps and institutional affiliations. 